Assiut University web-site: $\underline{\text { www.aun.edu.eg }}$

\title{
EFFECT OF GUARDIZEN-M AS A PROBIOTIC ON SOME BLOOD PARAMETERS AND HISTOLOGICAL STRUCTURE OF SOME INTERNAL ORGANS OF NILE TILAPIA OREOCHROMIS NILOTICUS
}

\author{
S.Y. HUSSEIN ${ }^{1}$, O.S. AFIFI ${ }^{2}$, M.G. ABDELFATTAH ${ }^{3}$, AHMED A.G. TOLBA ${ }^{4}$ \\ AND HANAN H. ABDEL-HAFEEZ ${ }^{5}$ \\ ${ }^{1}$ Prof. of Fish Physiology - Dept. of Poultry Production -Fac. of Agri. Assiut University \\ ${ }^{2}$ Prof. of Poultry Physiology - Dept. of Poultry Production Fac. of Agri. Assiut University \\ ${ }^{3}$ Associate Prof. Dept. of Poultry Production -Fac. of Agri. Assiut University \\ ${ }^{4}$ B.Sc. Poultry Production Dept. - Fac. of Agri. Assiut University \\ ${ }^{5}$ Associate Prof. Anatomy, Embryology and Histology Dept. Fac. of Vet. Med. Assiut University
}

Received: 31 August 2020; Accepted: 1 October 2020

\begin{abstract}
This work aimed to evaluate the effect of different dietary levels of Guardizen-M as a probiotic on some blood parameters and histological structure of some internal organs of Nile tilapia. The experimental design was completely randomized; a total number of 180 Nile tilapia with average weight $68 \pm 2.66 \mathrm{~g}$ and total length $15.41 \pm 0.27 \mathrm{~cm}$. were reared in 12 floating cages. The fish groups were distributed as four treatments and three replicates; a control group and three Guardizen-M treated groups $(1 \mathrm{~g} / \mathrm{kg}$ feed, $2 \mathrm{~g} / \mathrm{kg}$ feed, and $3 \mathrm{~g} / \mathrm{kg}$ feed). All experimental groups were fed the experimental diets at a rate of $3 \%$ of the live body weight of the fish. The results of the present work revealed that no significant $(\mathrm{P}>0.05)$ differences were recorded in blood parameters except in glucose and alkaline phosphatase. Histological studies of liver and intestine indicated that increase epithelial height of enterocytes lining the intestinal villi with increase in acidic secretion of goblet cells. The intensity of the Periodic acid-Schiff (PAS) staining increased proportionally with the increasing of the concentration of probiotics in treatment groups in comparison to control. Alkaline phosphatase activity revealed a difference among three experimental groups in comparison to control one. Results of the current study concluded that reversal effect of probiotics considering the proportion of dose. The greater area of hepatic cells increased proportionally with an increasing of the concentration of probiotics and created a greater area of nutrient storage as observed in hepatic cells.
\end{abstract}

Keywords: Probiotic, Blood Parameters, Immune response, Nile Tilapia

\section{INTRODUCTION}

It well noted that, particularly in developing countries, the shortage of human dietary protein can be provided by fish protein where protein shortage is

Corresponding author: Dr. S.Y. Hussein E-mail address: Samir.youssif@agr.au.edu.eg

Present address: Prof. of Fish PhysiologyDepartment of Poultry Production-Assiut University- Egypt. serious. Otherwise, this goal may be difficult due to the high cost of good quality fish meals which costs about $40-60 \%$ of total operating costs in intensive aquaculture enterprises (FAO, 1983 and Watanabe, 2002). This problem may be solved by culturing the great economic importance fish and using untraditional rations with low cost. Recently, tilapia culture is widely practiced in many tropical and subtropical regions of the world, since more than 22 tilapia species are being 
cultured worldwide, particularly the developing countries for cheap abundant and palatable protein source (Doudet, 1992 and Myers et al., 1995). Moreover, tilapia is the third largest group of farmed finfish species, only after carps and salmonids (FAO, 1997).

In Egypt, the wide spread of tilapia may be due to its resistance to disease, very hard, robust fish, high tolerance to adverse environmental conditions, relatively fast growth, as well as its high potential in fish farming and their good flesh texture and taste (Head and Splane, 1979; Hulata et al., 1993 and Eldar et al., 1995).

Over the past decades the growth of aquaculture as an industry has accelerated; this has resulted in environmental damages and low productivity of various crops. The need for increased disease resistance, growth of aquatic organisms, and feed efficiency has brought about the use of probiotics in aquaculture practices. The first application of probiotics occurred in 1986 to test their ability to increase growth of hydrobionts (organisms that live in water). Later, probiotics were used to improve water quality and control of bacterial infections. Nowadays, there is documented evidence that probiotics can improve the digestibility of nutrients, increase tolerance to stress, and encourage reproduction. Currently, there are commercial probiotic products prepared from various bacterial species such as Bacillus sp., Lactobacillus sp., Enterococcus sp., Carnobacterium sp., and the yeast, Saccharomyces cerevisiae among others, and their use is regulated by careful management recommendations (Patricia Martınez Cruz et al ., 2012).

Some gastrointestinal bacteria have been demonstrated to enhance the growth of fish (Limsuwan and Lovel, 1981). Moreover Gatesoupe (1991) reported the benefit of using Lactobacillus plantarum and Lactobacillus helveticus in turbot, Scophthalmus maximus (L.), and leading to enhance growth with turbot larvae,
Scophthalmus maximus. Rengpipat et al. (1998) found that Bacillus improved the survival of larvae, increased food absorption by enhancing protease levels and gave better growth. Probiotic bacteria can be added directly to the water or administered to the larvae via live food, such as rotifers and artemia (Skjermo and Vadstein, 1999).

Muroga et al. (1987) used lactic acid bacteria (LAB) for improvements of the non-specific immune response system or the intestinal microbial flora may reduce the mortality significantly. Probiotics may provide an alternative way to reduce the use of antibiotics in aquaculture and simultaneously avoid the development of antibiotic-resistant bacteria (Salminen et al., 1999).

Organs such as intestine and liver were associated with digestion, absorption of nutrients, and detoxification process in the body. Therefore, monitoring the pathological changes of these organs is considered necessary (Takashima et al., 1982 and Roberts, 1989). They are the most important organs in assessing the effects of ingredients used as raw materials of animal/ plant origin (Roberts, 1989). Estimation the efficiency of the digestive system and feeding habitats using histological structures is considered a good indicator of the nutritional status of fish (Hall and Bellwood, 1995, and Caballero et al., 2003). Histological picture of the intestine of fish is a prominent method in assessing the effects of supplementary nutrients (Chowdhary et al., 2013). Morphophysiological condition of the liver, as well associated with feeding process (Caballero et al., 2003; Ostaszewska et al., 2005). It is considered as a good indicator of nutritional pathology due to its function as a detoxification of metabolizing products coming from the digestive tract. It is the key organ of metabolism, excretion, and detoxification of the blood (Surai, 2015). Furthermore, studying the intestinal changes is necessary to understand 
histological picture promoted by any novel nutritional source (Gargiulo et al., 1997).

\section{MATERIALS AND METHODS}

The present study was carried out at the experimental fish farm belonging to the Poultry Production Department, Faculty of Agriculture, Assiut University. This experiment was designed in order to study the effect of GUARDIZEN $M$ on blood parameters, and histological structure of some internal organs of Nile tilapia Oreochromis niloticus in floating cages. The experiment started in July 2019 and lasted up to October 2019. The objective of this experiment was to assess the influence of the different inclusion levels of probiotic in the processed feed on some blood parameters, intestine and liver histomorphology of Nile tilapia, Oreochromis niloticus.

\section{Management of experimental fish:}

Nile tilapia Oreochromis niloticus with an average initial body weight of $68 \pm 2.66 \mathrm{~g}$ and $15.41 \pm 0.27 \mathrm{~cm}$. total length. was used in this experiment. The fish were obtained from the experimental fish farm belonging to the Zoology Department, Faculty of Science, Alazhar University-Assiut Branch. The experimental fish were adapted for two weeks in floating cages in a water pond. At the start of the experiment, a total number of 180 healthy fish were chosen. The fish were weighed and measured for the total length, and then distributed randomly into four experimental groups (45 fish each) as follow: first group was considered as a control which fed on the basal diet, the second, third and fourth group were fed on the basal diet with additional Guardizen-M $1 \mathrm{~g} / \mathrm{kg}, 2 \mathrm{~g} / \mathrm{kg}$ and $3 \mathrm{~g} / \mathrm{kg}$, respectively.

\section{Diet preparation:}

The dry ingredients of the experimental diets were thoroughly grinded, mixed and made in a pelleted form by addition of tap water $(20 \%)$. The paste was then extruded through a commercial mincing electric machine type Omega. The resulting spaghetti like diet $(1.5 \mathrm{~mm}$ for small fish and $2.5 \mathrm{~mm}$ diameter for bigger ones) was then air dried and stored in plastic bags till used. The proximate analysis of the experimental diet is shown in (Table 1). Fish were adapted to the experimental conditions for two weeks on the diet formulated according to (Eid and El-Gamal, 1996). All the experimental groups were fed the experimental diet at a rate of $3 \%$ of the live body weight of the fish. The feed quantity was readjusted biweekly on the basis of the actual average biomass of the fish in each treatment.

GUARDIZEN $\mathbf{M}$ was purchased by DONG BANG CO., LTD., Korea. Which made by mixed Probiotics and Each kg contains:

1-Mixed Probiotics Concentrates $5.6 \mathrm{~g}$ (min. 1 x 1010 CFU) Lactobacillus plantarum, Lactobacillus bulgaricus, Lactobacillus rhamnosus, Lactobacillus acidophilus, Bifidobacterium bifidum, Streptococcus thermophilus Enterococcus faecium, Aspergillus oryzae, Candida pintolopesii

2- Lactose or Dextrose 994.4g)

Table (1): The composition of the experimental basal diet:

\begin{tabular}{|c|c|}
\hline Ingredient & Weight (Kg) \\
\hline Yellow corn grain & 52 \\
\hline Soya bean meal & 22 \\
\hline Fish meal (72\% protein) & 25 \\
\hline Vitamin Mix. & 0.5 \\
\hline Mineral Mix. & 0.5 \\
\hline Total ingredients & 100 \\
\hline Crude protein $\%$ & 30.44 \\
\hline Gross energy $(\mathrm{Kcal} / \mathrm{Kg})$ & 4038.50 \\
\hline
\end{tabular}




\section{The floating cages:}

The experiment was carried out in one floating cages $(6 \mathrm{mX} 4 \mathrm{mX} 2 \mathrm{~m})$ which was divided into 12 portions $(2 \mathrm{mX} 1 \mathrm{mX} 2 \mathrm{~m})$ as shown in Fig1. The number of 15 fish was reared in each separate unit.

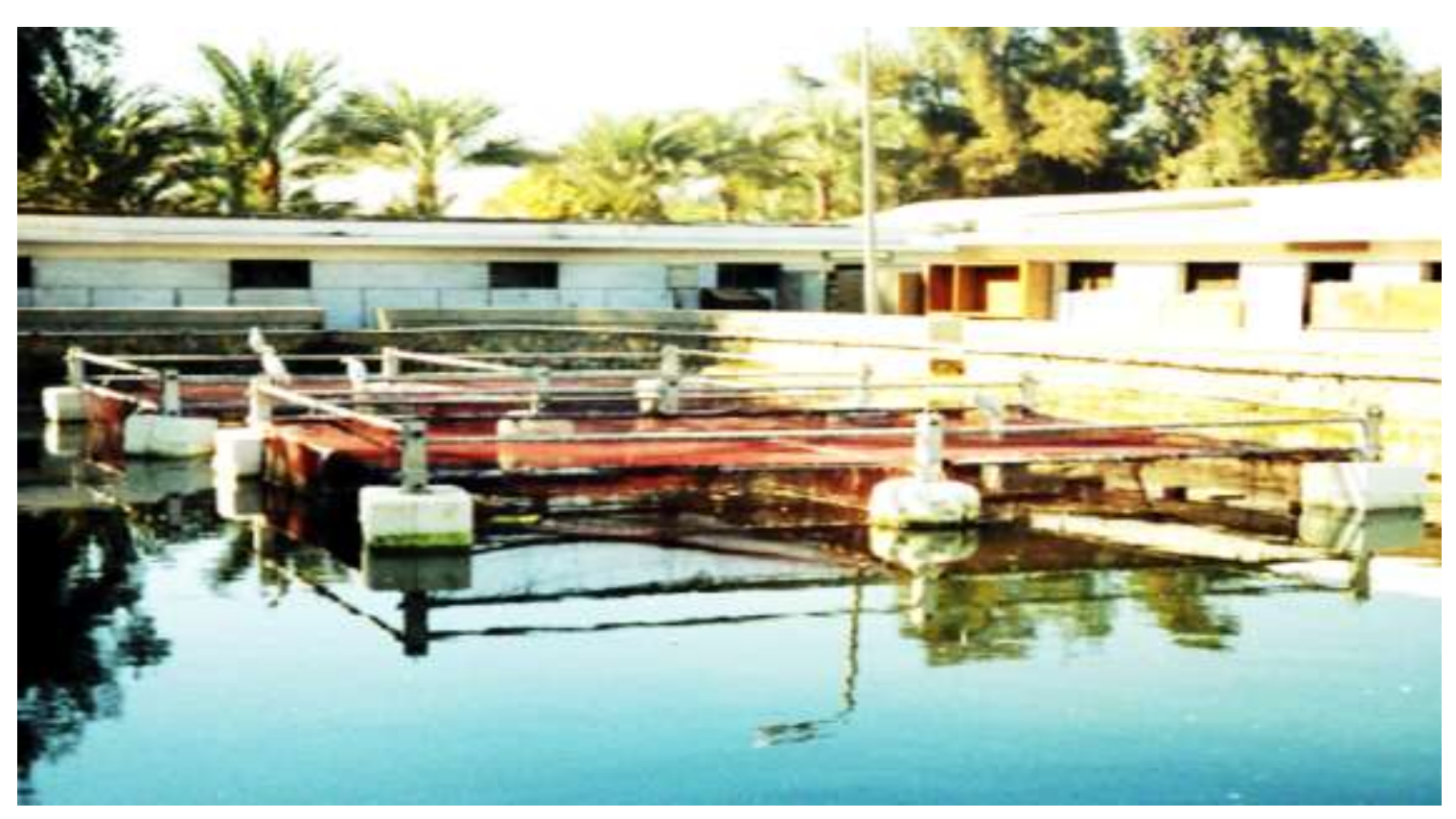

Fig. 1: The floating cages in water pond in fish farming

Blood samples: At the end of the experimental period 10 fish were randomly taken from each experimental group. The blood samples from each fish of the different groups were collected by suction of the caudal peduncle. Whole blood samples were collected in small plastic vials containing heparin for determination of hemoglobin $(\mathrm{Hb})$ and hematocrit $(\mathrm{PCV}$ $\%)$. The hemoglobin $(\mathrm{g} / \mathrm{dl})$ concentrations were determined by using commercial Kits (Spectrum Company for Biotechnology Co. Egypt) and the hematocrit (PCV \%) was measured according to Stoskopf (1993).

Other blood samples were collected and transferred to centrifuge tubes and allowed to clot at room temperature. Serum was then separated by centrifugation at 3000 (rpm) for 20 minutes. The serum was stored at $-20^{\circ} \mathrm{C}$ until analysis for total protein, albumin, alkaline 6 phosphatase, glucose. Serum total protein $(\mathrm{g} / \mathrm{dl})$, albumin $(\mathrm{g} / \mathrm{dl})$, and glucose (mg \%) were determined calorimetrically using Kits supplied by Spectrum company for Biotechnology (Egypt). Serum globulin (g/dl) levels were obtained by differences between total protein $(\mathrm{g} / \mathrm{dl})$ and albumin $(\mathrm{g} / \mathrm{dl})$. Serum alkaline phosphatase $(\mathrm{u} / \mathrm{l})$ activity was determined calorimetrically using commercial Kits purchased from Spectrum Company for Biotechnology (Egypt).

\section{Histological Study}

At the end of the experiment, three fish from each treatments and control group were taken for the microscopic structure. The middle part of anterior intestine and liver specimens about $3 \mathrm{~m}^{3}$ were immediately fixed in Bouin's fluid (for 24 hours) at room temperature. One unfixed selected specimens were used for frozen sections for alkaline phosphatase staining. The fixed specimens were dehydrated in an ascending series of ethanol, cleared in 
methyl benzoate and then embedded in paraplast (Sigma Aldrich). Transverse and longitudinal paraffin sections were obtained at $5 \mu \mathrm{m}$ thickness using a Richert Leica RM 2125 Microtome (Germany) and stained with Harris's Hematoxylin and Eosin for general histological examination (Suvarna et al., 2013).

Histochemical stains: Representative sections from intestine were stained with Alcian blue $(\mathrm{pH}$ 2.5) demonstrates acid mucins in tissue and stains them blue. Repesntive section from liver were stained by PAS stain for demonstration of glycogen and mucoplolyscaccharide content. In addition, sections were stained with Crossomon's trichrome. The sections were examined with a light microscope. The staining protocols and used procedures were carried out following the descriptions of the histological techniques as reported by Suvarna et al. (2013).

Enzyme histochemistry: The histological techniques descriptions were performed according to Suvarna et al. (2013). Histochemical analysis of Alkaline phosphatase was performed on unfixed selected frozen sections $(10 \mu \mathrm{m})$ were obtained in Leica cryostat CM 1900-6-1 (Richert, Germany). Leitz Dialux 20 Microscope provided with a Canon digital camera (Canon Power shot A95) used to examine the stained sections and capture the images.

\section{Morphometrical measurements:}

Different histomorphometric parameters were performed using light microscopic images of three fish including enterocytes height is a useful histological parameter using the Fiji software (Image J) (Http:// Fiji.sc/Fiji). Using three fish from each treatment and use three different crosssections from each fish. All the measurements were expressed as average \pm standard deviation.

\section{Statistical analysis:}

Analysis of variance was conducted using the general linear models (GLM) procedure of SAS (SAS Institute, 1998 Licensed to UNIVERSITY OF MARYLAND USA. Proprietary Software Release 6.12 TS020). Duncan's multiple range tests was used to compare between means of the control and treated groups (Steel and Torrie, 1980). The model of analysis was as follows:

$$
\mathrm{Yij}=\mu+\mathrm{Ti}+\mathrm{Eij}
$$

$\mu=$ The overall mean.

$\mathrm{Ti}=$ The effect of treatment

Eij $=$ The random error.

\section{RESULTS}

\section{Hematological parameters:}

Results in Table 2 show no significant ( $\mathrm{P}>0.05)$ impacts on all blood parameters studied except glucose and alkaline phosphatase due to dietary Guardizein-M supplementation. It is noticeable that fish fed Guardizein-M at level $3 \mathrm{~g} / \mathrm{kg}$ and $2 \mathrm{~g} / \mathrm{kg}$ had the highest values of blood glucose $(98.80$ and $108.05 \mathrm{mg} / \mathrm{dl}$ ) comparing with other treated groups and control. The lowest values of the blood glucose were found in fish fed the dietary Guardizein-M at level $1 \mathrm{~g} / \mathrm{kg}$ diet (65.41mg/dl). Moreover, fish fed Guardizein-M at level $1 \mathrm{~g} / \mathrm{kg}$ and $2 \mathrm{~g} / \mathrm{kg}$ had the highest values of Alkaline phosphatase (91.54 and 90.2 U/I) among the other experimental groups. The highest value of Alkaline phosphatase being 91.54 at level $1 \mathrm{~g} / \mathrm{kg}$ diet vs. the lowest value 28.47 was recorded in the control group. 
Table 2: The average blood Parameters \pm S.E of Nile Tilapia Oreochromis niloticus fed dietary Guardizein-M for 12 weeks.

\begin{tabular}{|c|c|c|c|c|c|}
\hline \multirow[t]{2}{*}{ Parameters } & \multirow{2}{*}{$\begin{array}{c}\text { Control } \\
\mathrm{C}\end{array}$} & \multicolumn{3}{|c|}{ Guardizein-M } & \multirow[t]{2}{*}{ Pro } \\
\hline & & T1 $(1 \mathrm{~g} / \mathrm{kg})$ & $\mathrm{T} 2(2 \mathrm{~g} / \mathrm{kg})$ & T3 (3g/kg) & \\
\hline
\end{tabular}

Blood components

\begin{tabular}{lccccc}
$\begin{array}{l}\text { a) Hematology } \\
\text { 1) Hemoglobin (g/dl) }\end{array}$ & $7.83 \pm 0.57$ & $6.96 \pm 0.33$ & $7.54 \pm 0.35$ & $7.33 \pm 0.34$ & 0.5351 \\
\hline 2) Hematocrit \% & $27.5 \pm 1.35$ & $29.38 \pm 1.5$ & $27.35 \pm 1.11$ & $26.91 \pm 0.73$ & 0.6901 \\
\hline $\begin{array}{l}\text { b) Serum constituents } \\
\text { 1- Total protein (g/dl) }\end{array}$ & $5.91 \pm 0.35$ & $5.05 \pm 0.10$ & $5.59 \pm 0.38$ & $5.15 \pm 0.34$ & 0.1819 \\
\hline 2- Albumin (g/dl) & $4.34 \pm 0.27$ & $3.71 \pm 0.08$ & $4.15 \pm 0.38$ & $4.13 \pm 0.23$ & 0.4177 \\
\hline 3- Globulin (g/dl) & $1.57 \pm 0.11$ & $1.35 \pm 0.17$ & $1.45 \pm 0.07$ & $1.37 \pm 0.8$ & 0.2510 \\
\hline $\begin{array}{l}\text { 4- Glucose (mg \%) } \\
65.41 \mathrm{~b} \pm 1.16\end{array}$ & $56.2 \mathrm{~b} \pm 0.8$ & $98.80 \mathrm{a} \pm 3.26$ & $108.05 \mathrm{a} \pm 7.92$ & $<0.0001$ \\
\hline $\begin{array}{l}\text { 5- Alkaline } \\
\text { phosphatase (U/I) }\end{array}$ & $28.47 \mathrm{c} \pm 1.89$ & $91.54 \mathrm{a} \pm 2.35$ & $90.2 \mathrm{a} \pm 7.57$ & $41.94 \mathrm{~b} \pm 2.66$ & $<0.0001$
\end{tabular}

$a, b, c$ Means within rows differ $(\mathrm{P}<0.05)$ when superscripts differ

Histological parameters:

Intestinal histology: The intestinal villi showed an increase in epithelial height lining the intestinal villi in treatments groups when compared to the control one (Table 3 and figure 2). The morphology of the middle intestine of treatment groups when compared to control group show increase in acidic mucous secretion of goblet cells when stained by Alcian blue pH2.5 (fig. 3).

Table 3: The epithelial height lining the intestinal villi in treatments groups (Mean \pm SD)

\begin{tabular}{ccccc}
\hline Control & T1 $(\mathbf{1 g} / \mathbf{k g})$ & $\mathbf{T 2}(\mathbf{2 g} / \mathbf{k g})$ & $\mathbf{T 3}(\mathbf{3 g} / \mathbf{k g})$ \\
\hline Mean \pm SD & $27.89 \pm 6.49$ & $37.92 \pm 5.26$ & $46.54 \pm 5.84$ & $50.64 \pm 4.83$ \\
& & & \\
\hline
\end{tabular}

Liver histology: Histological analysis of the liver showed that the intensity of the PAS staining increased proportionally with an increasing of the concentration of probiotics (fig. 4) and alkaline phosphatase reaction (figure 5) in treated groups in comparison with control. In figure 4 , the greater area of hepatic cells increased proportionally with the increasing of the concentration of probiotics. 


\section{LEGENDS}

Figure 2: Photomicrographs of the paraffin section of anterior intestine of Oreochromis niloticus at the middleshowing the different in epithelial height between groups. A: control group, B: group1: C: group 2, D: group 3.A and B: Hematoxylin and eosin stain.B and D: Crossmon's trichrome

Figure 3: Photomicrographs of the paraffin section of anterior intestine of Oreochromis niloticus at the middle fed different levels of probiotics showing increase in mucus production of goblet cells $\mathrm{A}$ and $\mathrm{B}$ : control group, $\mathrm{C}$ and $\mathrm{D}$ : group $1, \mathrm{E}$ and $\mathrm{F}$ : group2, $\mathrm{G}$ and $\mathrm{H}$ : group 3 . Arrowheads indicates kocation of goblet cells.
Figure 4: Photomicrographs of the paraffin section of Liver from different groups revealed a difference among three types of treatment in PAS reaction. A and $\mathrm{B}$ : control group, $\mathrm{C}$ and $\mathrm{D}$ : group 1, E and F: group2 .G and H: group 3. The intensity of the PAS staining increased proportionally with the increasing of the concentration of probiotics in treated groups in comparison to control group. Note: Greater area in hepatic cells increased proportionally with the increasing of the concentration of probiotics $(\mathrm{B}, \mathrm{D}$, $\mathrm{F}$, and $\mathrm{H}$ ).

Figure 5: Photomicrographs of the frozen section revealed a difference among three groups of treatment in alkaline phosphatase activity in comparison to control group. The intensity increase in groups 1 and 2 in comparison to control and decrease in group 3 .

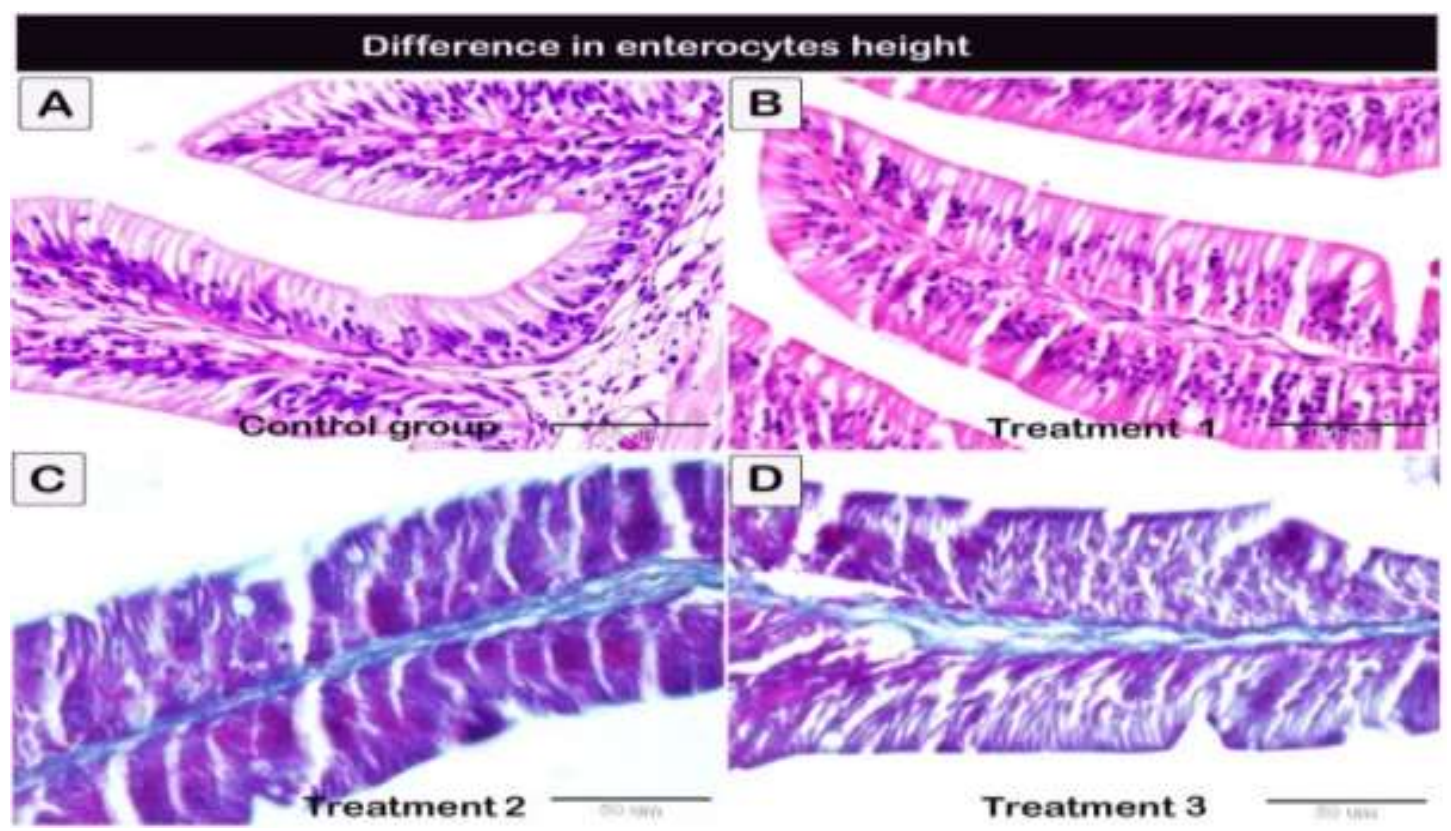

Fig. (1) 


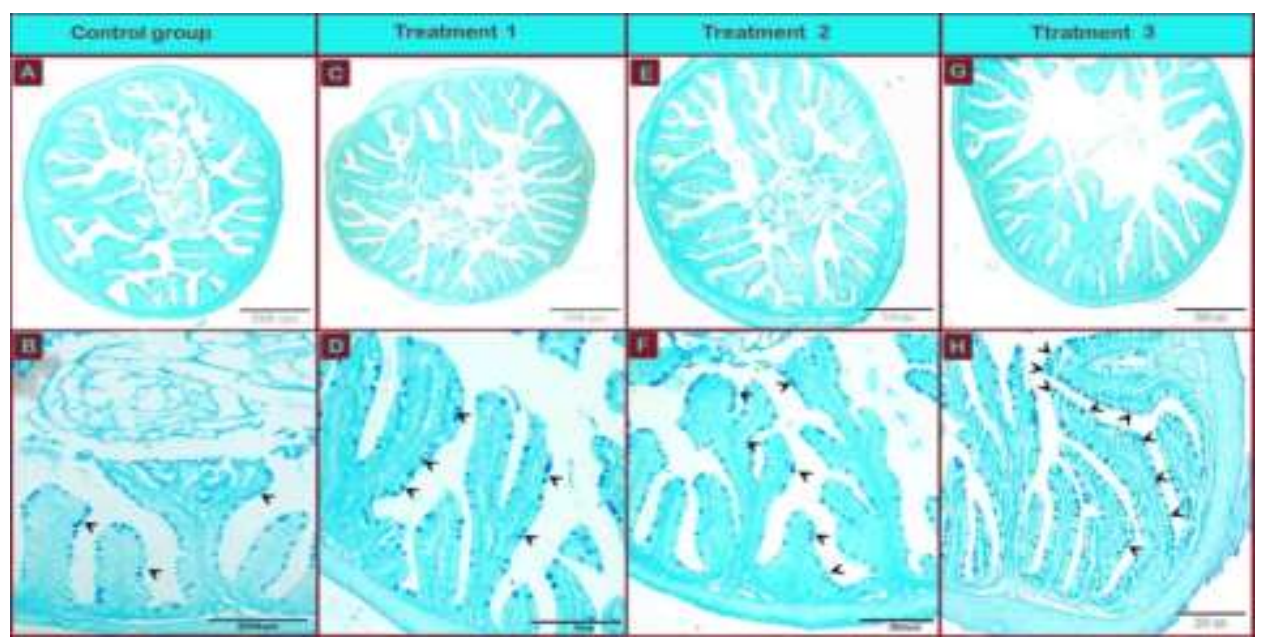

Fig. (2)

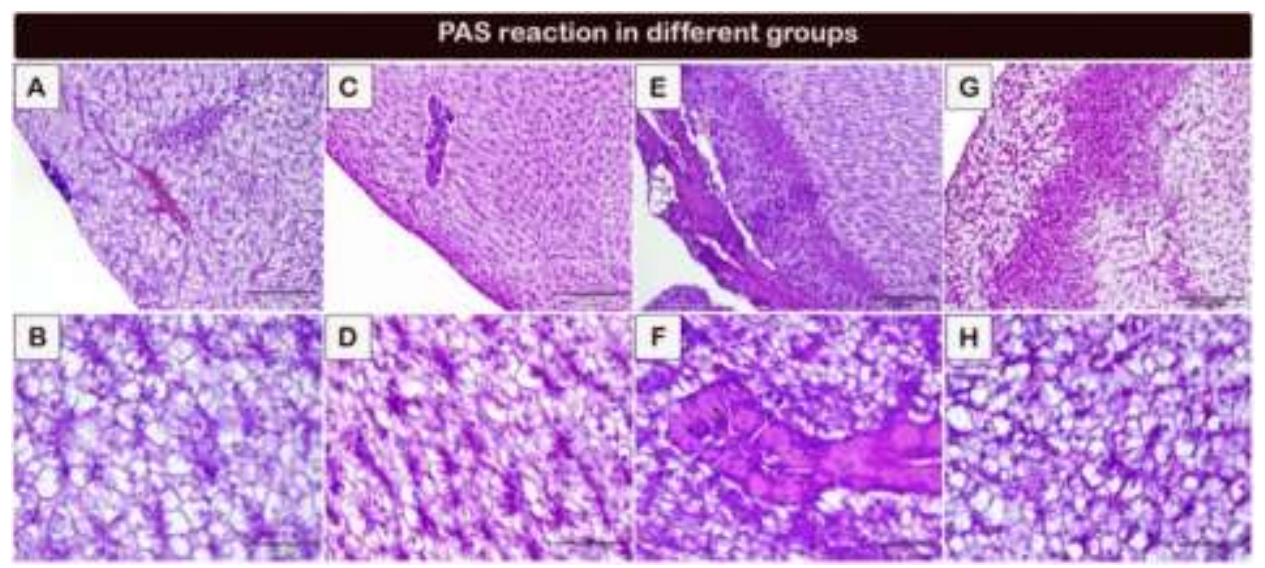

Fig. (3)

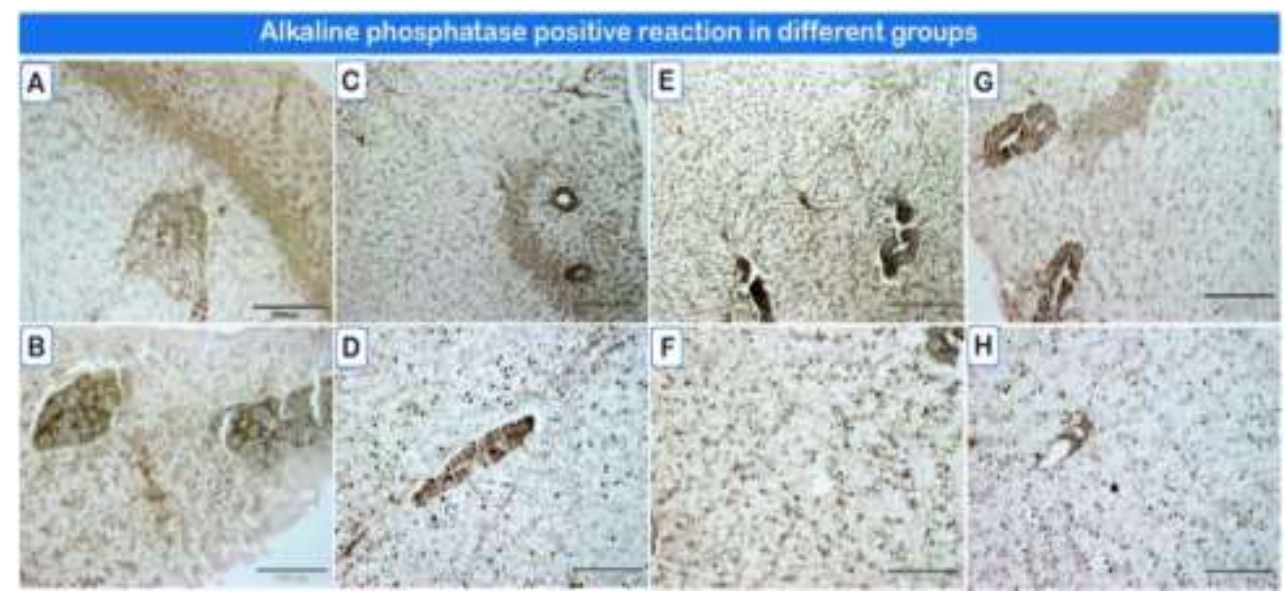

Fig. (4) 


\section{DISCUSSION}

The obtained results of the experiment exhibit that blood glucose and alkaline phosphatase were increased by Guardizein$M$ than that control group. These results were agree with those obtained by AlDohail et al. (2009) who found that the probiotic group had higher nutrient absorption rates and improved enzyme activates than the control group. Recently, Yang et al. (2019) reported that serum glucose was increase due to dietary bacillus supplementation. They found that dietary bacillus supplementation could elevated the activity of amylase in intestine together with an increase in serum glucose of red sea bream (Zaineldin et al., 2018). Also Yang (2019) indicated that $b$. cereus supplementation had positive impact on the carbohydrate metabolism and promote the use of carbohydrate.

In the same trend the utilization of various strategies in the assessment of the impacts of feed on intestinal and liver histology is essential. Strategies for decision in numerous investigations are semiquantitative techniques, since they are not tedious, and are simple for assessment of tests, yet they are not objective as others. Morphometric techniques are more pertinent than semi-quantitative (Rašković et al., 2011).

The outcomes show the probiotic increment increase in the height of enterocytes or epithelial height of lamina epithelials of musousa of middle intestine in treatments group in comparison to control group. The obtained data agreed with findings of Medri et al. (1999) and Sliva et al. (2005). According to Hisano et al. (2006) who explained the rise in epithelial height promoting a rise in area for absorption within the mucosa of intestine of Nile Tilapias fed diet supplemented with yeast.
Salinas et al. (2008), Ringo et al. (2010) and Merrifield et al. (2010) demonstrated enhancements in the morphology of the intestinal microvilli of the salmonides when added probiotics to the fish feed. Sweetman et al. (2008) reported that the interactions between the intestinal microflora, morphology of the intestine, immune system and absorption of nutrients may influence the health and performance of the fishes. Jesus et al. (2017) emphasized that the probiotic did not induce tissue damage and/or intestinal inflammation, demonstrating the power to enhance and maintain healthy intestinal structure. Mucosal surfaces of the fish gut considered the crucial first line of defense against the threats present in the immediate environment (Lazado and Caipang, 2014).

Previous studies demonstrated the role of mucosa to the overall health and welfare of fish and at securing optimum conditions in controlled aquaculture environments (Beck and Beatmon 2015; Lazado et al., 2015). This mucosal surface secreted by mucous and goblet cells contains inhibitory activity against pathogens, with potent molecules present in the matrix including mucins, lysozymes, complement proteins, lectins, antimicrobial peptides, and immunoglobulin, among many others (Nigam et al., 2012; Ellis, 2001). The mechanism of the mucosal surfaces involves the concerted action of physical barriers such as mucus, scales, and epithelium, which orchestrate the first line of defense by trapping and by direct elimination of pathogens (Cabillon and Lazado, 2019).

Liver of fish fed on probiotic supplemented diets showed the PAS staining increased proportionally with the increasing of the concentration of probiotics in treatment groups in comparison to control group. The intensity of alkaline phosphatase (AP) activity increase in-group 1 and 2 in comparison to control and decrease in- 
group 3 indicate reversal effect of probiotics considering with proportion of dose and created a greater area of nutrient storage as observed in hepatic cells. It could be concluded that the best level of Guardizein-M as growth promoter in Nile Tilapia diet was $1 \mathrm{~g} / \mathrm{kg}$ feed.

\section{REFERENCES}

Al-Dohail, M.A.; Hashim, R. and Paiko, M.A. (2009): Effects of the probiotic, Lactobacillus acido-philus, on the growth performance, haematology parameters and immunoglobulin concentration in African Catfish (Clarias gariepinus, Burchell 1822) fingerling. Aquaculture Research, 40, 1642-1652.

Beck, B.H. and Peatman, E. (2015): Mucosal Health in Aquaculture, 1st Ed.; Academic Press: Cambridge, MA, USA.

Caballero, MJ.; Izquierdo, MS.; Kjфrsvik, E.; Montero, D.; Socorro, J.; Fernández, AJ. and Rosenlund, $G$. (2003): Morphological aspects of intestinal cells from gilthead seabream (Sparus aurata) fed diets containing different lipid sources. Aquaculture. 225:325-340.

Caballero, M.J.; Izquierdo, M.S.; Kjorsvik, E.; Fernandez, A.J. and Rosenlund, G. (2004): Histological alterations in the liver of sea bream, Sparus aurata L., caused by short- or long-term feeding with vegetable oils. Recovery of normal morphology after feeding fish oil as the sole lipid source. Journal of Fish Diseases 27:531-541.

Cabillon, N.A.R. and Lazado, C.C. (2019): Mucosal barrier functions of fish under changing environmental conditions. Fishes, 4(1), 2.

Chowdhary, S.; Srivastava, P.P.; Jena, J.; Yadav, A.K.; Dayal, R.; Mishra, S. and Srivastava, S.M. (2013): Histological studies of the intestine in threatened Asian catfish (Clarias batrachus) fingerlings fed with animal or plant origin protein blended with glucosamine. International Journal of Fisheries and Aquatic Studies. 1(2):50-55.

Doudet, T. (1992): Brackishwater tolerance of some species and hybrids of Oreochromis for use in lagon aquaculture (Ivory Cost). Aquaculture, 102: 275-288.

Eid, A.E. and El-Gamal. (1996): Effects of stocking density on growth performance of Nile tilapia (Oreochromis niloticus) reared in three different culture systems. J. Anim. Prod., 33 (Special Issue): 485 498.

Eldar, A.; Frelier, P.F.; Assenta, L.; Varner, P.W.; Lawhon, S. and Bercovier, H. (1995): Streptococcus shiloi, the name for an agent causing septicemic infection in fish, is a junior synonym of Streptococcus iniae. Int J Syst Bacteriol 45:840 842.

Ellis, A.E. (2001): Innate host defense mechanisms of fish against viruses and bacteria. Dev. Comp. Immunol. 25, 827-839.

FAO, (1983): Fish feeds and feeding in developing countries - UNDPL FAO. ADCP REP, 83 (13), pp 97.

FAO, (1997): Food and Agriculture Organization of the United Nations, Aquaculture Production Statistics 1986-1995. FAO Fish. Circ. No. 815, Rev. 9, Rome, Italy. 179 pp.

Gargiulo, A.M.; Ceccarelli, P.; Dall'aglio, C. and Pedini, V. (1997): Ultrastructural study of the stomach of Tilapia spp. (Teleostei). Anatomia, Histologia, Embryologia 26:331-336.

Gatesoupe, F.J. (1991): The effect of three strains of lactic bacteria on the production rate of rotifers, Brachionus plicatilis, and their dietary value for larval turbot, Scophthalmus maximus. Aquaculture 96:335-342. 
Hall KC, Bellwood DR. (1995): Histological effects of cyanide, stress and starvation on the intestinal mucosa of Pomacentrus coelestis, a marine aquarium fish species. Journal of Fish Biology, 47:438-454.

Head, W. and Splane, J. (1979): Fish farming in your solar greenhouse. Amity Foundation. 16-17 pp.

Hisano, H.; Silva, M.D.P.; Barros, M.M. and Pezzato, L.E. (2006): Levedura íntegra ederivados do seu processamento em rações para tilápia do Nilo: aspectos hematológicos e histológicos. Acta Scientiarum. Biological Sciences. 28(4): 311-318

Hulata, G.; Wohlfarth, W.G.; Karplus, I.; Schroeder, G.L.; Harpaz, S.; Halevy, A.; Rothbard, S.; cohen, S.; Israael, I. and Kavessa, M. (1993): Evaluation of Oreochromis niloticus $\mathrm{X} O$. aureus hybrid progeny of different deographical isolates, reared under varying management regimes. Aquaculture, 115: 253-271.

Jesus, G.F.A.; Vieira, F.D.N.; Silva, B.C.; Junior, M.M.D.S.; Ushizima, T.T.; Schmidt, E.C.; Bouzon, Z.L.; Pereira, S.A.; Pereira, S.A.; Martins, M.L. and Mouriño, J.L.P. (2017): Probiotic bacteria may prevent haemorragic septicaemia by maturing intestinal host defences in Brazilian native surubins. Aquac. Nutr., 23, 484-491.

Lazado, C.C. and Caipang, C.M.A. (2015): Mucosal immunity and probiotics in fish. Fish Shellfish Immunol. 2014, 39, 78-89; Salinas, I. The Mucosal Immune System of Teleost Fish. Biology, 4, 525-539.

Lazado, C.C.; Caipang, C.M.A. and Estante, E.G. (2015): Prospects of host-associated microorganisms in fish and penaeids as probiotics with immunomodulatory functions. Fish Shellfish Immunol. 45, 2-12.

Limsuwan, T. and Lovel, R.T. (1981): Intestinal synthesis and absorption of vitamin B-12 in channel catfish. J. Nutr. 111, 2125- 2132.

Medri, V.; Pereira, G.V.; Leonhardt, J.H.; Panini, M.S. and Dietzel, S. (1999): Avaliação sensorial de filés de tilapias alimentadas com diferentes níveis de levedura alcooleira. Acta Scientiarum. Animal Sciences. 21(2): 303- 308.

Merrifield, D.L.; Harper, G.; Baker, R.T.M.; Ringo, E. and Davies, S.J. (2010): Possible influence of probiotic adhesion to intestinal mucosa on the activity and morphology of rainbow trout (Oncorhynchus mykiss) enterocytes. Aquaculture, 302(1-3): $1-18$.

Muroga, K.; Higashi, M. and Keitoku, H. (1987): The isolation of intestinal micro-flora of farmed red seabream Acanthopagrus schlegeli at larval and juvenile stages. Aquaculture 65, 7988.

Myers, R.A.; Barrowman, N.J.; Hutchings, J.A. and Rosenberg, A.A. (1995): Population Dynamics of Exploited Fish Stocks at Low Population Levels. Science, New Series, Volume 269, Issue 5227 (Aug. 25, 11061108.

Nigam, A.K.; Kumari, U. and Mittal, A.K. (2012): Comparative analysis of innate immune parameters of the skin mucous secretions from certain freshwater teleosts, inhabiting different ecological niches. Fish Physiol. Biochem. 38, 1245-1256.

Ostaszewska, T.; Dabrowski, $\quad K$.; Czuminska, K.; Olech, W. and Olejniczak, M. (2005): Rearing of pikeperch larvae using formulated diets-first success with starter feeds. Aquaculture Research 36:1167-1176.

Patricia Martınez Cruz; Ana L. Iba'nez; Oscar A. Monroy Hermosillo and Hugo C. Ramırez Saad (2012): Use of Probiotics in Aquaculture. International Scholarly Research 
Network,Volume 2012, Article ID 916845,13 pages.

Rašković, Božidar S.; Marko B. Stanković; Zoran Z. Marković and Vesna D. Poleksić. (2011): "Histological methods in the assessment of different feed effects on liver and intestine of fish." Journal of Agricultural Sciences (Belgrade) 56 (1): $87-100$.

Rengpipat, S.; Phianphak, W.; Piyatiratitivorakul, $\quad$ S. and Menasveta, P. (1998): Effects of a probiotic bacterium in black tiger shrimp Penaeus monodon survival and growth. Aquaculture 167, 301313.

Ringo, E. and Gatesoupe, F.J. (1998): Lactic acid bacteria in fish: A review. Aquaculture 160:177-203.

Ringo, E.; Lovmo, L.; Kristiansen, M.; Salinas, I.; Myklebust, R.; Olsen, R.E. and Mayhew, T.M. (2010): Lactic acid bacteria vs pathogens in the gastrointestinal tract of fish: a review. Aquaculture Research. 41(4): 451-467.

Roberts, R.J. (1989): Baillière Tindall, The nutritional pathology of teleosts. In: Fish pathology. Baillière Tindall, London.

Salinas, I.; Myklebust, R.; Esteban, M.A.; Olsen, R.E.; Meseguer, J. and Ringo, E. (2008): In vitro studies of Lactobacillus delbrueckii subsp. lactis in Atlantic salmon (Salmo salar L.) foregut: tissue responses and evidence of protection against Aeromonas salmonicida subsp. salmonicida epithelial damage. Veterinary Microbiology. 128(1-2): 167-177.

Salminen, S.; Ouwehand, A.; Benno, Y. and Lee, YK. (1999): Probiotics: how should they be defined? Trends Food Sci. Technol. 10: 107-110.

SAS Institute, (1998): Licensed to UNIVERSITY OF MARYLAND USA. Proprietary Software Release 6.12 TS020.
Silva, N.; Gurgel, $H$. and Santana, M. (2018): Histologia do sistema digestório de sagüiru, Steindachnerina notonota (Miranda Ribeiro, 1937) (Pisces, Curimatidae), do rio Ceará Mirim, Rio Grande do Norte, Brasil. Boletim do Instituto de Pesca, 31(1), 1-8.

Skjermo, J. and Vadstein, O. (1999): Techniques for microbial control in the intensive rearing of marine larvae Aquaculture 177, 333-343.

Steel, R.G.D. and Torrie, J.H. (1980): Principles and Procedures of Statistics: A Biometrical Approach (2nd Ed.). McGraw-Hill Inc., New York.

Stoskopf, M.K. (1993): Clinical Pathology in Fish Medicine. WB Saunders Company, New York, USA., Pages: 251.

Surai, P. (2015): Silymarin as a natural antioxidant: an overview of the current evidence and perspectives. Antioxidants, 4(1), 204-247.

Suvarna, K.S.; Layton, C. and Bancroft, J.D. (2013): Bancroft's Theory and Practice of Histological Techniques. 7th ed. Oxford, Churchill Livingstone Elsevier, pp.654.

Sweeteman, J.; Dimitroglou, A.; Davies, S. and Torrecillas, S. (2008): Nutrient uptake: gut morphology a key to efficient nutrition. International AquaFeed. 11: 27-30.

Takashima, F. and Hibiya, T. (1982): An atlas of fish histology: normal and pathological features. Kodansha, distributed by Fischer, G., Tokyo, 147.

Watanabe, T. (2002): Strategies for further development of aquatic feeds. Fish. Sci. 68, 242-252.

Yang, G.; Cao, H.; Jiang, W.; Hu, B.; Jian, S.; Wen, C.; Kajbaf, K.; Kumar, V.; Tao, Z. and Peng, M. (2019): Dietary supplementation of Bacillus cereus as probiotics innPengze crucian carp (Carassius auratus var. Pengze): Effects on growth performance, fillet 
quality, serum biochemical parameters and intestinal histology. quaculture Research, 50:2207-2217.

Zaineldin, A.I.; Hegazi, S.; Koshio, S.; Ishikawa, M.; Bakr, A.; El-Keredy, A.M. and Yukun, Z. (2018): Bacillus

subtilis as probiotic candidate for red sea bream: Growth performance, oxidative status, and immune response traits. Fish \& Shellfish Immunology, 79, 303-312.
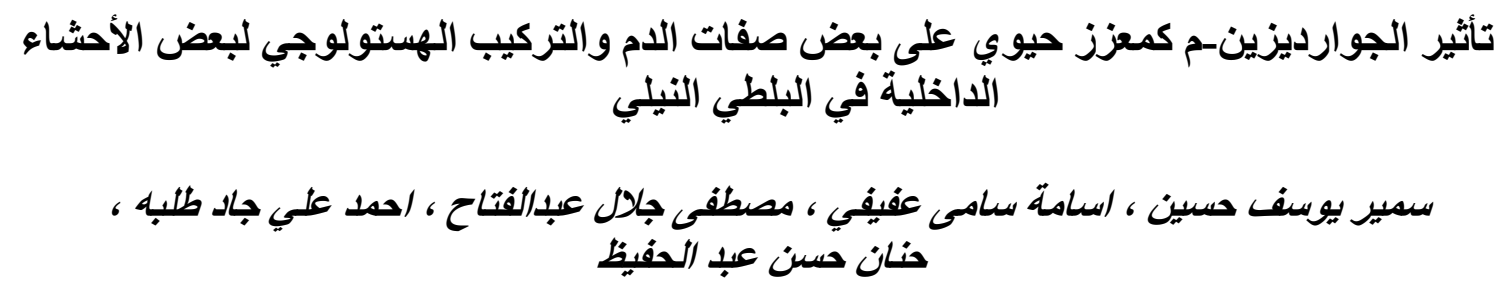

Email: $\underline{\text { Samir.youssif@agr.au.edu.eg, Assiut University web-site: www.aun.edu.eg }}$

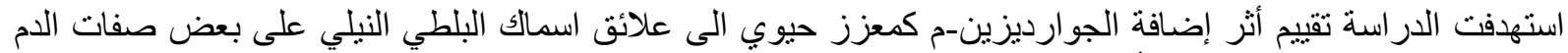

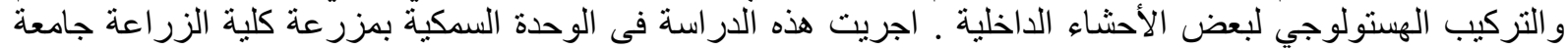

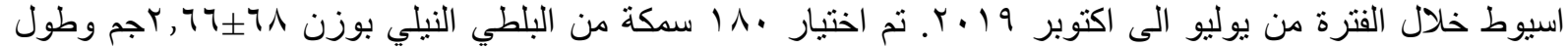

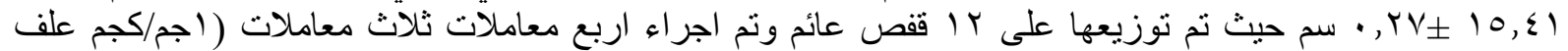

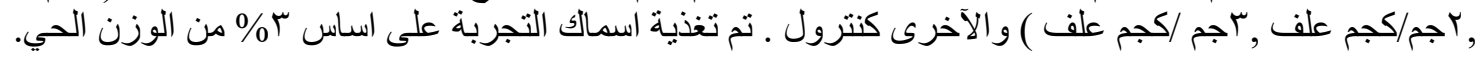
أوضحت النتائج المتحصل عليها انه لا توجد فروق معنوية بين المعاملات بالنسبة لصفات الدام ما عدا جلوكوز الدام الداء

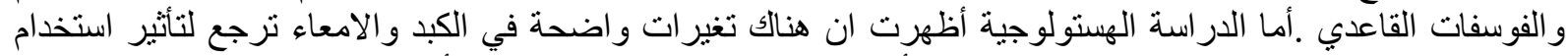

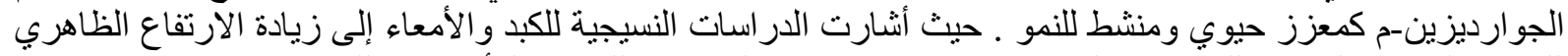

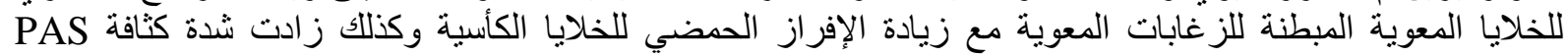

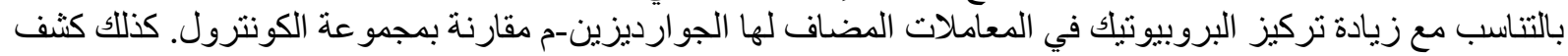

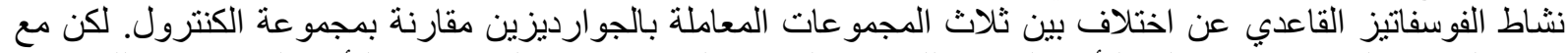

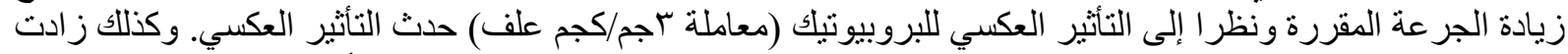

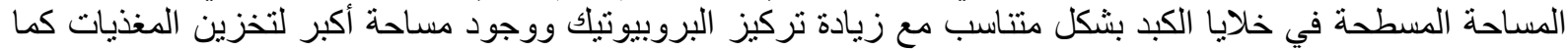
لوحظ ذللك في خلايا الكبد ولذلك يوصى باستخدام الجوارديزين-م كمنشط للنمو عند مستوى الجم /كجم علف علف. 